\title{
E-learning in Foreign Language Instruction in Turkey: Curriculum Models and Course Design Guidelines
}

\author{
Ferit KILIÇKAYA* \\ Jarosław KRAJKA** \\ Małgorzata LATOCH-ZIELIŃSKA ${ }^{* * * *}$
}

\begin{abstract}
Nowadays, the implementation of e-learning, blended learning and distance learning in foreign language instruction has become widespread all over the world, including Turkey. With the generation of Digital Natives learning at schools, instructors face the challenge of providing distance learning courses and materials that would meet necessary standards. The reevaluation of curriculum models and evaluation criteria is thus needed to ensure high quality of distance instruction. The present paper will report on different models of distance learning courses, reflecting on their applicability for English language teaching in Turkey. Moreover, course design guidelines will be provided to facilitate effective authoring of online programs.

Key Words: E-learning, Language Instruction, Curriculum Models, Course Design.

\section{Introduction}

Computer technology has helped to introduce a number of innovations into foreign language instruction. The widespread use of methods, activities and tools of Computer-Assisted Language Learning (CALL) enabled many teachers all over the world, including Turkey, to enhance their teaching and maximise learning opportunities for their students. Fortunately, more and more schools on the one hand and

\footnotetext{
* Assist. Prof. Dr., Faculty of Education, Mehmet Akif Ersoy University, Turkey, ferit.kilickaya@gmail.com

** Assist. Prof. Dr., Warsaw School of Social Sciences and Humanities, Poland, jaroslaw.krajka@swps.edu.pl

*** Małgorzata Latoch-Zielińska, Maria Curie-Skłodowska University, Poland gosialz@poczta.onet.pl
} 
households on the other have computers and Internet access to make technology-assisted learning possible.

Out of different forms of CALL, distance learning deserves its special place. Contrary to such well-established branches as multimedia CALL, Data-Driven Learning or Internet-assisted Language Learning, teaching foreign languages at a distance still awaits greater attention and development in the future. What is especially needed is the reflection on different modes of learning and their applicability to particular national contexts conditioned by, among others, learners' cultural preferences.

The aim of this paper is to address the notion of distance learning as a possible source of inspiration for innovation in English language learning and teaching in Turkey. The discussion of development of Information Society and distance education will be followed by elaboration on fundamental concepts involved in e-learning. The presentation and critical discussion of different distance learning initiatives implemented at Turkish educational establishments will conclude the present chapter.

\section{Development of Information Society and Distance Education}

One of the most fundamental aims of contemporary education on each level should be preparing students to function properly in the information society as well as find their proper place in knowledge-based reality (Myrdzik \& Latoch-Zielińska, 2010).

The notion 'Information Society', IS for short, was used for the first time in 1963 by Tadao Umesao in the article about the evolutionary theory of society based on information (Nowak, 2005) and was made famous with the seminal work of Kenichi Koyama Introduction to the Theory of Information published in 1968. However, the development of Information Society originated in the United States in 1956-1957, when the number of whitecollar workers exceeded the number of manual labourers. The industrial America gave way to the society that for the first time in history was dominated by those dealing with information rather than production of goods.

The contemporary world demands skilful and reflective use of information, and it has become essential for people to develop their intelectual abilities, for education to be information-oriented, for communication to be computerised. At the same time, home computer terminals and nation-wide computer networks were introduced (GobanKlas \& Sienkiewicz, 1999). In Europe, the idea of Information Society was 
made one of the pillars of knowledge-driven economy, together with education and science, which promised catching up with the USA in terms of economic development.

The most important influence for the development of Information Society was the report of the European Commission known as The Bangemann Report (European Council, 1994). The report sparked off wide debate across Europe on the possibilities of balanced development and increasing the economic potential, as well as indicated dangers connected with the development of innovative information technologies and their influence on society.

During the late 1990s many analyses, reports, and strategic documents on key directions of the development of Information Society were prepared. To start with, "Towards an Information Society Approach" green paper was issued by the European Commission in 1997 (European Commission, 1997), and the initiative "eEurope - An Information Society for All" was proposed in December 1999 (European Commission, 1999). Within this strategy, the issues of Information Society became strongly grounded in politics as a topic of discussion of member states and institutions of the European Union and a factor contributing to the process of European integration.

The complete plan for building the European Information Society, known as "Lisbon Strategy", was passed at the European Union summit in Lisbon in 2000. After that, a number of key documents were prepared that clearly detailed specific actions and milestones. In 2000 at the summit in Feira "eEurope 2002 - An Information Society for All" action plan was passed, while in Gothenburg the need for modernisation and acceleration of reforms in candidate countries was further refined (European Commission, 2002). At Seville summit "eEurope 2005 Information Society for All" plan obliged EU member states to develop electronic services, introduce electronic health service, and provide universal Internet access. However, the "European Information Society 2010" plan that passed at the Council of Europe summit in May 2005 proclaimed information technologies as the driving force of permanent growth and a precondition for the information society (European Commission, 2005).

The Turkish Ministry of National Education started distance education programs in the 1970s, preparing delivery of programs in English and French to support the curricula at schools through a state radio, Radio Ankara. In the 1980s, in coordination with the state TV, TRT prepared foreign language teaching programs as well as other ones (Adiyaman, 2002). In accordance with the Higher Education Act of 1981, Anadolu University 
started to provide distance education in Turkey. In 1982, Anadolu University started to offer undergraduate distance education degrees in business administration and economics using digital versions of textbooks, streamed versions of broadcast TV programs, audio books, and multimedia learning materials. Following wide-scale adoption of computers in schools starting from the 1990s and the educational reform in 1997, Departments of Computer Education and Instructional Technology were established to train teachers in the field of computers and computer education. Since then, many universities and private institutions have started to provide distance education through various tools supported by technology.

\section{Fundamental Concepts of Distance Education}

To start with, a number of basic concepts related to online learning and distance education need to be established. Many of them are used interchangeably (Pachler \& Daly, 2011), however, crucial differences that occur between these call for ample discussion in the present chapter. The general definition of e-learning is proposed by Daly and Pachler (2010) as follows:

A set of practices that enhance the potential of people to learn with others via technology-aided interaction, in contexts that can be "free" of barriers of time and place. It involves the utilisation of a range of digital resources - visual, auditory, and text-based - which enable learners to access, create and publish material which serves educational purposes. ... this material can be shared electronically with fellow learners and teachers both within and beyond the bounds of formal education contexts (p. 217)

- Distance education is a form of learning in which individual students or distributed groups of students are taught by a teacher, however, without being in constant contact.

- Distance learning is a learning context in which both student and teacher are separated by geographical and temporal distance, which results in individual learning with little or no cooperation with other students.

- Distributed learning, on the other hand, is a form of distance education in which students can fully interact with both one another and the instructors.

- E-learning, finally, is the process of education that uses innovative methods of transmitting knowledge via the Internet, extranet and 
intranet technologies, audio, video, flash animations and the like (Zielińska, 2011).

At the same time, one can distinguish a number of modes of distance learning, classified according to the type of technology used and the character of the learning process:

- databases - the simplest form of online education, in which students have online (Internet, intranet) or offline (CD, DVD) access to multimedia encyclopedias, libraries, training materials etc.;

- online consultations - quick answers to questions asked by Internet or intranet users, the exchange of information and knowledge via email, newsletters, discussion forums, chats or FAQ systems;

- synchronous mode - the teacher and the student are in constant contact and both parties influence each other at the same time. This mode encompasses such techniques as audioconferences, videoconferences, interactive television or Internet chats. This format of learning features live interaction, individual as well as group work and discussions. Students are given access to source materials and tools, which can be presented, processed, collected, deleted, changed or monitored. Each student activity or its absence can be easily spotted.

- asynchronous mode - does not demand the presence of students and teachers at the same time in the same place. The former choose the moment they want to learn in, while the latter specify the topics, pace the content delivery, set deadlines for tasks, tests, modules and courses. This mode uses, among others, audio and video resources, websites, e-mail, discussion forums. The advantages of this format are that students can learn from any place rather than at school, they can access materials at any time and from any place, get more time to reflect as opposed to the synchronous mode. Moreover, this mode is more cost-effective, as the very cost of materials development depends on the level of sophistication of contents and the very system used.

- Blended mode - the most effective teaching model that mixes traditional and virtual forms of content delivery.

Currently, three most popular distance learning environments can be distinguished:

- Learning Management System (LMS), which enables administration and delivery of content, monitoring learner progress and assigning access rights to particular modules and courses to individual students or groups of learners; 
- Learning Course Management System (LCMS), which, apart from LMS functions described above, also feature functionalities for didactic content authoring (so-called Web-Based Training, WBT);

- Mixed models. These are generally composed of five modules (Latoch-Zielińska, 2009):

$\checkmark$ subject management module, which is responsible for scheduling the availability of subjects in the system, publishing content and tracking learning of enrolled students;

$\checkmark$ distance self-study module, enabling learners to use distance courses and collecting information about their progress;

$\checkmark$ communication module, allowing synchronous and asynchronous communication;

$\checkmark$ course builder module, with which the teacher can design course templates and introduce content into them;

$\checkmark$ quiz module, which allows the teacher to create quiz tasks for teacher-administered exams or self-study quizzes for students.

\section{Language Education in the E-Learning Context}

It is generally believed that distance education, contrary to traditional learning, is more modern, effective, and attractive. Even though this point is frequently debated by many educationalists, the present paper will adopt a more positive view of distance learning in language education, placing less attention on the drawbacks or limitations of this form of learning.

As far as positive aspects of online education are concerned, Watkins (2005) distinguishes the following:

- focusing the learning process on the student,

- individualising the learning curriculum and adapting it to the student's needs,

- setting the learning pace according to one's preferences,

- distributing learning units regardless of the time and place,

- encouraging critical and contextual thinking through promoting problem-based learning,

- fostering cooperation of students,

- emphasising teacher-student dialogue,

- allowing access to educational resources not only related to a single lesson, but using rich multimedia libraries. 
According to Stanisławska (n.d.), distance education meets the most fundamental standards of teaching: message complexity, curriculum cohesion, difficulty grading, presentation systematicity, knowledge durability, initiativeness, and conscious learning. One particular aspect that needs to be stressed here is that distance education promotes problem-based learning, cooperative learning and learning to learn.

Moreover, online learning meets the assumptions of the constructivist approach to language education, within which students learn in interaction with their surrounding and are active at construing their knowledge by evoking previously learnt information (Dylak, 2000). In this paradigm, learners do not record ready-made information, but rather construct their own structures based on data. The constructivist view on teaching and learning stresses the active role of the learner in creating his/her self-identity.

Contemporarily, there has been a shift in roles observed, from teacher as monitor (Restricted CALL), through teacher as monitor and facilitator (Open CALL) to teacher as facilitator and manager (Integrated CALL - Bax, 2003). Goodyear, Salmon, Spector, Steeples, and Tickner (2001) and Goodyear (2001, p. 91) have derived a set of indicators for how both tutor and student roles might be expected to change when moving from traditional to online teaching and learning (Table 1).

\section{Table 1: Changing Teacher Roles}

- From oracle and lecturer to consultant, guide, and resource provider

- Teachers become expert questioners, rather than providers of answers

- Teachers become designers of learning student experiences rather than just providers of content

- Teachers provide only the initial structure to student work, encouraging increasing self- direction

- Teacher presents multiple perspectives on topics, emphasising the salient points

- From a solitary teacher to a member of a learning team (reduces isolation sometimes experienced by teachers)

- From teacher having total autonomy to activities that can be broadly assessed

- From total control of the teaching environment to sharing with the student as fellow learner

- More emphasis on sensitivity to student learning styles

- Teacher-learner power structures erode 
Together with wider adoption of problem-based learning and collaborative learning, new roles for teachers such as "facilitators of learning" as opposed to "deliverers of content" have been enforced (Naidu, Cunnington, \& Jasen, 2002). E-teacher accompanies the e-learner in the process of gathering knowledge and becoming familiar with the outside world. The most important aim for the former is helping the latter understand objective reality and use acquired knowledge. Instead of being lectured, the student gets assignments to be done, which are constructed in such a way that they involve drawing one's own conclusions and observations, as well as searching for alternative solutions. In order to tackle a particular problem the student needs to collect the necessary knowledge $\mathrm{him} /$ herself. This mode of learning is much more effective than getting a bunch of data to be remembered, which would be followed by showing the applications.

Teachers are "called upon to abandon traditional roles and act more as guides and mentors, exploring the new media themselves as learners and thus acting as role models for their learners" (Fitzpatrick \& Davies, 2003, p. 4). In some contexts of CALL, such as distance education, the change might even result in inapplicability of the term 'teacher', to be replaced by 'tutor', 'e-moderator' (Salmon, 2004) or 'pedagogue' due to its connotations of 'supervision' and 'guardianship' as well as 'instruction' (Hult, Dahlgren, Hamilton, \& Söderström, 2005).

Distance education encompasses the plethora of methods, forms and tools to be used by the teacher. The selection of the most appropriate method is determined on the one hand by the objectives set, while on the other hand by teacher and learner capabilities. Horton (2006) enumerates the factors that contribute to the process of learning in distance contexts. He stresses the fact that each of these can be encountered in the distance-learning environment, and each can have its appropriate ways of implementation.

Learning by listening can be fostered by providing links to online audio and video resources, audio and videoconferences, e-learning courses, recordings of conferences and seminars. Seeking truth will take place when the teacher uses e-mentoring, discussion groups, mailing lists, chats, individual online research, as well as other mechanisms of virtual community building. Learning by reading is triggered by the use of textual resources, virtual libraries, hyperlinks to online resources. Learning by viewing, on the other hand, will be facilitated by introducing online audio and video, conference and workshop recordings, screen sharing and 
whiteboards. Students can also learn through investigating case studies, when they are directed to virtual museums and laboratories, when they examine cases or when they are engaged in mechanisms of group criticism.

Furthermore, learners can acquire knowledge by modelling their or others' behaviour, which is accomplished by e-mentoring, using guest experts during lessons, incorporating case studies, roleplaying, simulations, games and tests in the course of the lesson. One can also learn through trying out and exploring, by being engaged in simulations, virtual labs, brainstorming or manuals. Moreover, discussion as an activity is also not to be underestimated, and it is fostered by the e-teacher with discussion groups, mailing lists, chats, e-mentoring and other forms of virtual community building. Remembering and practising are foundations of education, thus, activities related to practice or mnemonics can be used to maximise the memorisation process. Finally, students will conduct research through individual searches on the Internet, teacher-directed exploration of online resources or analyses of selected cases.

\section{Blended Learning as the Most Effective Format of Distance Education}

Both research and practice show that blended learning, as a paradigm mixing face-to-face and online components, is the most effective solution for foreign language learning (Garrison \& Kanuka, 2004). Blended learning can have different forms: "implementing e-learning solutions in foreign language learning makes the whole process less time-consuming and more closely related to individual preferences and learning styles of students" (Czos, 2006, para. 6).

To sum up, the most important advantages of blended learning are the following (Goltz-Wasiucionek, 2010):

- Shaping the teaching process flexibly through using e-learning units and traditional lessons in different configurations.

- Modyfing, updating and expanding content quickly and easily.

- Administering the teaching process and monitoring learner progress easily through transferring some part of their learning onto the virtual platform.

- Providing varied forms of work and assessment: among others, objective and customised feedback delivered automatically right after the completion of the task or quiz, as opposed to delayed or non-existent feedback in traditional learning. 
- Extending students' exposure to the target language out-of-class, enabling individual work at one's own pace with communication with the teacher via a forum or internal mail.

In the framework of foreign language learning, blending the two components means, in practical terms, that the teacher can apply online activities to develop students' written skills such as reading comprehension and writing, while use face-to-face lessons to focus on oral proficiency and authentic use of language in communication. In addition, effectiveness of grammar instruction can be significantly increased by automated e-learning activities due to their multiple types, options and number. Listening comprehension is another skill that is fundamental for acquiring language proficiency. However, using audio recordings in traditional learning encounters many problems: limited time in class, the necessity to take all students at the same pace, the need to play the recording the same amount of times to the whole class. On the other hand, the provision of audio materials and accompanying quizzes on the e-learning platform enables students to listen to materials as many times as they prefer, as well as use a tapescript or a dictionary at one's demand. If possible, stand-alone pronunciation software or speech recognition systems can be integrated with the online course to provide appropriate language model and opportunities for individual pronunciation practice.

\section{Distance Course Design Guidelines}

The foundation for making online courses is the Instructional Design educational theory, which specifies the techniques aiming at activating the student in the process. While designing distance courses, the following set of nine steps put forward by Robert M. Gagné is universally adopted (as cited in Latoch-Zielińska, 2009):

- Motivate the Learner - use attractive teaching materials, encompass learners of different learning styles and modalities, apply varied forms of work to provide equal chances to all learners.

- Explain What is to Be Learned - at the start of the course, define precisely what kind of knowledge and/or skills students are expected to achieve at its end. Use hyperlinking to allow learners to exercise their choice in navigating the material, even though this might mean losing track of important issues or skipping some fundamental concepts. 
- Recall Previous Knowledge - show connections with the old knowledge, provide links to material introduced in some other lesson of the course, construct examples and tasks which require previous knowledge to be brought to the new task.

- Present the Material to be Learned - the course designer needs to reconcile students' learning styles and preferences with the specific conditions of online work, so that particular learning units do not devote more than 15-20 minutes to lectures, and the greatest part of the lesson is taken up by discussions, group work, projects and case studies. Theoretical knowledge can be summarised in an accompanying pdf. file, a list of references or links to online resources.

- Provide Guidance for Learning - plan hints or cues for learners to facilitate individual work, include a large number of examples with practical applications of the presented aspect of knowledge, provide frequently asked questions with answers.

- Active Involvement - create the learning environment that would stimulate different forms of work, most of all, discussions and group work.

- Provide Feedback - think about cues and hints given to the learner while doing tasks or taking quizzes, which would guide him or her to correct answers without the need to send messages to the instructor.

- Test Comprehension - make provisions for instructors to assess students' progress not only through tasks and automatic quizzes, but also by planning individual or group projects, with presentation and discussion of results delivered to the whole group via a forum.

- Provide Enrichment or Remediation - encourage learners to consolidate and expand their newly acquired knowledge and skills by indicating links to related websites, using a glossary or highlighting additional reading sources.

A typical online learning unit needs to encompass the following elements (see, for instance, the structure of learning units in the e-Academy of the Future e-learning project, Szaleniec, 2009):

- introduction: title page and summary of contents,

- aims and objectives - specifying expected results of students' learning,

- links - indicating relations of the current unit with previous 'lessons', 
- introducing new knowledge - presenting new aspects of knowledge, be it a grammatical structure, a set of lexical items, or a reading text with a new topic,

- practising new knowledge - interactive activities based on new knowledge which aim at practising skills,

- consolidating new knowledge - automatic revision of the most important aspects of the unit and interactive tests with automatic grading,

- feedback - information to what extent the aims of the learning unit have been accomplished and further actions to be taken if the result is unsatisfactory.

\section{Using the E-Learning Platform in Educating Language Teachers}

Distance education can be successfully applied in all areas of life based on traditional methods of acquiring knowledge. Most of all, its implementation can enhance the process of language teacher training, as teachers will inevitably be expected to not only use traditional means of expression, but put to work digital tools as well.

The issue of teacher literacies necessary for conducting technologyenhanced instruction needs to be carefully considered. Warschauer (2002, p. 455) has identified four electronic literacies that include

computer literacy (i.e., comfort and fluency in keyboarding and using computers), information literacy (i.e., the ability to find and $c$ ritically evaluate online information), multimedia literacy (i.e., the ability to produce and interpret complex documents comprising texts, images, and sounds), and computer-mediated communication literacy (i.e., knowledge of the pragmatics of individual and group onlineinteraction).

Warschauer's competences are not ordered hierarchically, instead, they are skills that overlap for a complete and successful CALL practitioner.

For Daud (1992), the main issues from a CALL class demanding teacher training implications involve exposure to different kind of software and platforms, how to teach together with the computer, how to manipulate the available software, how to handle students in this type of classes, how to integrate CALL into the curriculum and how to select appropriate software to suit different courses.

Russell, Rebell, O'Dwyer, and O'Connor (2003, p. 301) yield a similar list of seven distinct categories of teacher technology use as follows: 
- Teacher use of technology for preparation

- Teacher use of technology for delivery

- Teacher-directed student use of technology

- Teacher use of technology for special education and accommodation

- Teacher use of e-mail

- Teacher use of technology for recording grades

Carballo-Calero (2001) adds to the list the four essential skills, such as searching (for specific information using varied computer-based information sources), evaluating (the quality and applicability of computerbased materials), creating (text-based and multimedia digital artefacts to be published on the Web) and integrating (the new technology in their teaching in the most applicable way).

More specifically, a foreign language teacher conducting instruction at a distance should possess the following skills (Gajek, 2004):

- the ability to use e-learning tools with confidence,

- the ability to upload teaching materials and announcements to the platform,

- the ability to hold synchronous and asynchronous discussions,

- the ability to analyse the learning process based on the logs of the system (e.g., student access time, the number of quiz attempts or the number of views for specific resources),

- the ability to modify and adapt textual, audio and video materials to suit them to the needs of students,

- the ability to use electronic databases to enhance the process of materials authoring.

All these skills can be developed during pre-service training courses at university, when teacher trainees are put into the shoes of e-learners. The experiences collected in this way will surely result in their greater openness and enthusiasm towards new technological developments in the future.

\section{The Current E-Learning Trends in Turkey}

The current trends in Turkey considering distance education and elearning in teaching English can be categorized into three main streams: asynchronous discussion forums created by individuals or language teachers to provide discussion on several aspects of the English language, fully distance education English language programs which are provided by some commercial companies and universities and, finally, Web- or CDbased learning aiming at providing intensive activities to improve language learning skills such as reading and writing. 
Learning materials used in asynchronous discussion forums created by individuals or language teachers (Özyurt \& Özyurt, 2010) include lecture notes in plain documents and multimedia formats, monolingual and bilingual dictionaries and question-answer sessions where people pose questions and provide answers to some aspects of the English language, mainly centred around grammar, reading and vocabulary questions. The majority of discussion forum users also share materials that they create by themselves or the ones that have been prepared by some private language schools or language teachers, which address some difficulties faced by the Turkish learners of English. Some of the most popular websites are Ingilizce Sitesi (http://www.ingilizcesitesi.com), Dil Forum (http://www.dilforum.com) and English Office (http://englishoffice.ipbfree.com).

In fully distance education programs, learners can benefit from websites that are intended to guide them from pre-elementary to advanced levels of English through several units accompanied by various lecture notes and exercises. Learners can work according to their own pace and are supported through tools like audio recording, pronunciation and special monolingual and bilingual dictionaries, in order to facilitate understanding of the lexical items provided in exercises or reading passages. Grammar and writing activities are also supported by virtual classrooms. In addition to grammar and writing activities, the listening skill is practiced through several audio and video materials. Moreover, learners can have speaking sessions with online tutors on dates announced in advance. The sessions held with learners are recorded for subsequent review. The English Language School offered by Gazi University (http://dilokulu.gazi.edu.tr/) and the commercial website, İngilizce Okulu (http://www.ingilizceokulu.com/) are good examples of these fully distance education programs.

The studies conducted to find out to what extent fully distance education programs are effective show that the majority of the students did not enjoy the online learning as it lacked opportunities for practice and faceto-face natural interaction (İnözü \& İlin, 2007). According to the participants in the study, immediate feedback, teacher support and opportunities for real communication were expected from these programs and they stated that they would opt for a traditional classroom. This can be attributed to the fact that Turkish students, generally speaking, are teacher-dependendent and teachers are very at the center of the learning processes (Sakar, 2009). The cultural factors such as respect for authority and close interpersonal relationships can lead Turkish distance learners to experience difficulties 
with independent learning and unstructured learning environments (Uşun, 2004). In another study conducted by İnal, Karakuş, and Çağıltay (2008), despite their ICT skills, the majority of the Turkish high school students stated that they would not participate in fully distance education programs since face-to-face instruction and social climate of the traditional classroom would not be achieved. In another study confirming the findings of the previous studies (Sakar, 2009), the majority of the students again wanted to take face-to-face courses although they agreed that online courses were helpful.

On the other hand, Web and CD-based learning programs aim to provide intensive language activities to improve language learning skills such as reading and listening. The current studies in Turkey reveal that language teachers mostly focus on reading, writing, pronunciation, and vocabulary activities. Hişmanoğlu and Hişmanoğlu (2011) reported that Internet-based pronunciation activities helped Turkish learners overcome pronunciation difficulties. The studies related to reading skills (Sagin-Simsek, 2008; Tanyeli, 2009) showed Web-based learning environments could be a very efficient way of conducting reading classes. The studies conducted on vocabulary learning and teaching, hypermedia effect and the use of audiovisual materials such as captioned clips, all revealed very positive results and showed that learners did significantly better while acquiring new lexical items (Akbulut, 2007; Aydın, 2007; Kılıçkaya \& Krajka, 2010; Yüksel \& Tanrıverdi, 2009; Çakır, 2006). However, it is worth noting that listening, speaking skills and grammar knowledge seem to have been ignored as there is currently very little research conducted into these areas though especially listening and grammar activities really lend themselves to distance education or blended learning programs.

After reviewing the current trends, it will be useful to briefly discuss the recent studies focusing on the attitudes, beliefs, and conceptions. The recent studies show that language teachers, teacher candidates and students have overally positive attitudes towards technology and, according to them,technology has positive effect on EFL learning (Koçoğlu, 2008; Özek, Kesli, \& Koçoğlu, 2009; Çoklar \& Odabaşı, 2010; Hişmanoğlu, 2010; Baturay \& Daloğlu, 2010; Yüksel \& Kavanoz, 2011). However, female participants tended to have more negative attitudes towards technology (Yüksel \& Kavanoz, 2011), while in another study conducted by Hişmanoğlu (2010), the female participants had positive attitudes toward using the Internet. The positive and negative attitudes towards technology as shown by these studies can be attributed to the experiences of these participants with technology, such as the availability, accessibility, the technological tools 
introducted, and the appropriate uses of technology in teaching contexts provided at various stages of their education.

Putting together all the studies conducted on the use of technology and the attitudes of Turkish learners and teachers, it can be concluded that Turkish learners and language teachers are eager to benefit from the opportunities provided by distance education. However, Turkish learners require immediate feedback, teacher support, and opportunities for real communication to be taken into consideration, as they are not ready yet for independent learning and unstructured learning environments.

\section{Conclusion}

As indicated by the present paper, e-learning as a method of learning languages has great potential for foreign language instruction in Turkey. Even though some of the modes of learning at a distance might not be compatible with cultural conditions of Turkish students, the versatility of contemporary Learning Management Systems enables instructors to design their courses in such a way to address culturally conditioned preferences. With increased mobility of citizens distance learning will play more and more important role, and language teachers need to be properly trained as either course designers or programme facilitators. It is to be hoped that the discussion of e-learning types and modes, together with course design guidelines, will contribute to increasing the competence of Turkish teachers of foreign languages for their future distance teaching experiences.

Acknowledgement: This article is the revised and edited version of the chapter published under the same title in Innovations in English Language Teaching and Learning: The Turkish Perspective by Crowd Source ELT.

\section{References}

Adıyaman, Z. (2002). Uzaktan eğitim yoluyla yabancı dil öğretimi [Teaching foreign languages through distance education]. The Turkish Online Journal of Educational Technology, 1(1), 92-97. Retrieved from http://www.tojet.net/articles/v1i1/1111.pdf

Akbulut, Y. (2007). Variables predicting foreign language reading comprehension and vocabulary acquisition in a linear hypermedia environment. The Turkish Online Journal of Educational Technology, 6(1), 53-60. Retrieved from http://www.tojet.net/articles/v6i1/615.pdf 
Aydin, S. (2007). Attitudes of EFL learners towards the Internet. The Turkish Online Journal of Educational Technology, 6(3), 18-26.

Baturay, M. H., \& Daloğlu, A. (2010). E-portfolio assessment in an online English language course. Computer-Assisted Language Learning, 23(5), 413-428.

Bax, S. (2003). CALL - past, present and future. System, 31, 13-28.

Carballo-Calero, M. V. F. (2001). The EFL teacher and the introduction of multimedia in the classroom. Computer Assisted Language Learning, $14,3-14$.

Czos, D. (2006). Zastosowanie e-learningu w nauczaniu języków obcych

[Using e-learning in foreign language teaching]. Retrieved from http://kadry.nf.pl/Artykul/6924/Zastosowanie-e-learningu-wnauczaniu-jezykow-obcych/e-learning-szkolenia/.

Çakır, İ. (2006). The use of video as an audio-visual material in foreign language teaching classroom. The Turkish Online Journal of Educational Technology, 5(1), 67-72. Retrieved from http://www.tojet.net/articles/v5i4/549.pdf

Çoklar, A. N., Odabaşı, H. F. (2010). Are teacher candidates able to use educational technologies effectively? A case study in terms of standards. International Journal of Human Sciences, 7(2), 1-16.

Daly, C., \& Pachler, N. (2010). E-learning: The future? In J. Arthur \& I. Davies (Eds.), Routledge textbook on educational studies (pp. 216-26). London: Routledge.

Daud, N. M. (1992). Issues in CALL implementation and its implications on teacher training. CALICO Journal, 10(1), 69-78.

Dylak, S. (2000). Konstruktywizm jako obiecująca perspektywa kształcenia nauczycieli [Constructivism as a promising perspective for teacher training]. In H. Kwiatkowska, T. Lewowicki, \& S. Dylak (Eds.), Wspótczesność a kształcenie nauczycieli. Warsaw: WSP ZNP. Retrieved from http://www.cen.uni.wroc.pl/teksty/konstrukcja.pdf.

European Commission (1997). Towards an Information Society Approach. Green Paper on the Convergence of the Telecommunications, Media and Information Technology Sectors, and the Implications for Regulation. COM (97) 623 final, 3 December 1997. Retrieved from http://aei.pitt.edu/1160/1/telecom_convergence_gp_COM_97_623.pd f.

European Commission (1999). eEurope - An information society for all. Communication of 8 December 1999 on a Commission initiative for the special European Council of Lisbon, 23 and 24 March 2000 - eEurope - An information society for all [COM(1999) 687]. Retrieved from 
http://europa.eu/legislation_summaries/information_society/124221_ en.htm.

European Commission (2000). eEurope 2002 - An Information Society for All. Action plan prepared by the Council and the European Commission for the Feira European Council, 19-20 June 2000. Brussels: Council of the European Union/Commission of the European Communities. Retrieved from http://ec.europa.eu/information_society/eeurope/2002/documents/ar chiv_eEurope2002/actionplan_en.pdf.

European Commission (2002). eEurope 2005 Information Society for All. An Action Plan to be presented in view of the Sevilla European Council, 21/22 June 2002. Communication from the Commission to the Council, the European Parliament, the Economic and Social Committee and the Committee of the Regions [COM(2002) 263 final]. Brussels: Commission of the European Communities. Retrieved from http://ec.europa.eu/information_society/eeurope/2002/news_library/ documents/eeurope2005/eeurope2005_en.pdf.

European Commission (2005). i2010 - A European Information Society for growth and employment. Commission Staff Working Paper Communication from the Commission [SEC(2005) 717/2]. Brussels: Commission of the European Communities. Retrieved from http://ec.europa.eu/information_society/eeurope/i2010/docs/extende d_impact_assessment.doc.

European Council (1994). Europe and the global information society. Bangemann report recommendations to the European Council. Retrieved from http://www.umic.pt/images/stories/publicacoes200801/raport_Bange manna_1994.pdf.

Fitzpatrick, A., \& Davies, G. (Eds). (2003). The Impact of Information and Communications Technologies on the teaching of foreign languages and on the role of teachers of foreign languages: a report commissioned by the Directorate General of Education and Culture. Retrieved from http://ec.europa.eu/education/policies/lang/doc/ict.pdf.

Gajek, E. (2004). Nauczanie języków online [Teaching languages online]. eMentor 2/2004. Retrieved from http://www.e-mentor.edu.pl/artykul/index/numer/4/id/45.

Garrison, R., \& Kanuka, H. (2004). Blended learning: Uncovering its transformative potential in higher education. The Internet and Higher Education, 7(2), 95-105. 
Goban-Klas, T., \& Sienkiewicz, P. (1999). Społeczeństwo informacyjne: Szanse, zagrożenia, wyzwania. Cracow: Wydawnictwo Fundacji Postępu i Telekomunikacji.

Goltz-Wasiucionek, D. (2010). Blended learning w kształceniu językowym [Blended learning in language education]. e-Mentor 5/2010.

Retrieved from http://www.ementor.edu.pl/artykul/index/numer/37/id/793.

Goodyear, P. (2001). Effective networked learning in higher education: notes and guidelines. Retrieved from http://csalt.lancs.ac.uk/jisc/guidelines_final.doc.

Goodyear, P., Salmon, G., Spector, J. M., Steeples, C., \& Tickner, S. (2001). Competences of online teaching: a special report. Educational Technology Research and Development, 49(1), 65-72.

Hişmanoğlu, S. (2010). Attitudes of L2 teachers towards Internet-based foreign language teaching. Procedia Social and Behaviroal Sciences, 3, 106-111.

Hişmanoğlu, M., \& Hişmanoğlu, S. (2011). Internet-based pronunciation teaching: An innovative route toward rehabilitating Turkish EFL learners' articulation problems. European Journal of Educational Studies, 3(1), 23-36.

Horton, W. (2006). E-learning by design. Boulder: Pfeiffer.

Hult, A., Dahlgren, E., Hamilton, D., \& Söderström, T. (2005). Teachers' invisible presence in net-based distance education. International Review of Research in Open and Distance Learning, 6 (3), 1-11. Retrieved from http://www.irrodl.org/index.php/irrodl/article/view/262/839.

İnal, Y., Karakuş, T., \& Çağıltay, K. (2008). Turkish high school students' considerations, expectation and awareness on distance education. The Turkish Online Journal of Distance Education, 9(4), 63-76. Retrieved from http://tojde.anadolu.edu.tr/tojde32/articles/article_4.htm

İnözü, J. \& İlin, G. (2007). How do learners perceive e-language learning programs in their local context. The Asian EFL Journal Quarterly, 9(4), 278-286.

Kılıçkaya, F., \& Krajka, J. (2010). Comparative usefulness of online and traditional vocabulary learning. The Turkish Online Journal of Educational Technology, 9(2), 55-63. Retrieved from http://www.tojet.net/articles/v9i2/927.pdf

Koçoğlu, Z. (2008). Turkish EFL student teachers' perceptions on the role of electronic portfolios in their professional development. The Turkish Online Journal of Educational Technology, 7(3), 71-79. Retrieved from http://www.tojet.net/articles/v7i3/738.pdf 
Latoch-Zielińska, M. (2009). e-Kształcenie - nowe możliwości polonistyki. In A. Dziak \& S.J. Żurek (Eds.), e-polonistyka (pp. 207-217). Lublin: Wydawnictwo KUL.

Myrdzik, B., \& Latoch-Zielińska, M. (2010). Kształcenie nauczycieli do nowych zadań: przygotowanie uczniów do życia w społeczeństwie informacyjnym [Training teachers for new challenges: preparing students to function in the Information Society]. In M. Jędrychowska, D. Łazarska, \& E. Mikoś (Eds.), Studia ad Didacticam Litterarum Polonarum et Linguae Polonae Pertinentia II (pp. 113-123). Cracow: Wydawnictwo Naukowe Uniwersytetu Pedagogicznego w Krakowie

Naidu, S., Cunnington, D., \& Jasen, C. (2002). The experience of practitioners with technology-enhanced teaching and learning. Educational Technology \& Society, 5(1), 23-34. Retrieved from http://www.ifets.info/journals/5_1/naidu.html

Nowak, J. S. (2005). Społeczeństwo informacyjne - geneza i definicje [Information Society - origins and definitions]. Retrieved from http://www.infobrokerstwo.pl/index.php?option=com_content\&task $=$ view $\&$ id $=56 \&$ Itemid $=51$.

Özek, Y., \& Kesli, Y., \& Koçoğlu, Z. (2009). Integrating a web-based learning program into a traditional learning environment: Students' attitudes and expectations. US-China Education Review, 6(11), 80-86.

Özyurt, H., \& Özyurt, Ö. (2010). Investigation of English language learning activities in web-based environments including asynchronous discussion forums. E-journal of New World Sciences Academy, 5(2), 538-548.

Pachler, N., \& Daly, C. (2011). Key issues in e-learning: research and practice. London, New York: Continuum.

Russell, M., Rebell, D., O'Dwyer, L., \& O'Connor, K. (2003). Examining teacher technology use: Implications for pre-service and inservice teacher preparation. Journal of Teacher Education, 54(4), 297-310.

Sağın-Şimşek, C. S. (2008). Students' attitudes towards integration of ICTs in a reading course: A case in Turkey. Computers \& Education, 51, 200211.

Sakar, N. (2009). Online course support in distance learning: Student evaluation of English language teaching bachelor of arts program. The Turkish Online Journal of Distance Education, 10(2), 86-99. Retrieved from https://tojde.anadolu.edu.tr/tojde34/pdf/article_2.pdf 
Salmon, G. (2004). E-moderating: The key to teaching and learning online. London: Kogan Page.

Stanisławska A. K. (n.d.). Różnice i podobieństwa, zalety i słabości nauczania przez Internet versus nauczania tradycyjne [Differences and similarities, advantages and drawbacks of distance education versus traditional education]. Retrieved from http://www.puw.pl/downloads/docs/1_elearning/2_teoria_elearning /Stanislawska.pdf.

Szaleniec, H. (2009). Platformy e-learningowe oraz ich znaczenie dla organizacji procesu nauczania - uczenia się [E-learning platforms and their role for the organisation of the teaching/learning process]. Presentation given at Shaping Key Competences in Gymnasium Project conference, Warsaw, November 27-29, 2009. Retrieved from http://www.eakademiaprzyszlosci.pl/pub/files/Wystapienia/Platfor my_e-learningowe.ppt.

Tanyeli, N. (2009). The efficiency of online English language instruction on students' reading skills. Procedia Social and Behavirol Sciences, 1, 564567.

Uşun, S. (2004). Bilgisayar destekli öğretimin temelleri [The basics of computer assisted teaching]. Ankara: Nobel Yayın Dağıtım.

Warschauer, M. (2002) A developmental perspective on technology in language education. TESOL Quarterly, 36(3), 453-475.

Watkins, T. (2005). Exploring eLearning reforms for Michigan. The New Education (R)evolution. Detroit: Wayne State University.

Retrieved from

http://www.inacol.org/cms/wp-content/uploads/2013/07/elearningreport.pdf

Yüksel, D., \& Tanrıverdi, B. (2009). Effects of watching captioned movie clip on vocabulary development of EFL learners. The Turkish Online Journal of Educational Technology, 8(2), 48-54. Retrieved from http://www.tojet.net/articles/v8i2/824.pdf

Yüksel, G, \& Kavanoz, S. (2011). In search of pre-service EFL certificate teachers' attitudes towards technology. Procedia Computer Science, 3, 666-671.

Zielińska, J. (n.d.). Techniki zdalnego nauczania w kształceniu ustawicznym [Distance learning techniques in lifelong learning]. Retrieved from http://www.nettrainers-training.org 